formed in machining operations in non-metallic materials, such as plastics, this dust being difficult to displace by means of brushes or rags. In woodworking machinery it is very useful in removing sawdust and shavings. To enable the gun to be readily connected to existing air supplies, the manufacturers have developed a neat pressure-reducing tube valve manufactured from bronze pressings and having a diaphragm of the oil-resisting rubber insertion type. The valve will reduce an initial pressure of $150 \mathrm{lb}$. per sq. in. to any pressure between $5 \mathrm{lb}$. and $100 \mathrm{lb}$. per sq. in., the adjustment being made by a thumb screw. The valve has a nickelplated finish and is stated to be unaffected by oil or water and does not vibrate or chatter when in use.

\section{War, Tradition and Natural Beauty}

IN a war, which in so far as the greater includes the less, is being fought by the British people in defence of an ideal of the spirit which, we maintain, has run like a thread throughout our history, it is vital that every effort should be made to keep alive, even if necessary in attenuated form, activities which make for the preservation of the national tradition as embodied in our antiquities and places of historic interest, or in those vistas of our landscape which are not only beautiful in themselves, but also express something which is essentially in harmony with characteristics of the mentality of the British peoples. The recent pronouncement of the Council for the Preservation of Rural England makes a bold bid to reconcile claims arising out of present necessities with its objective of saving rural beauties from desecration.

How difficult this may become is strikingly illustrated in the recently issued report for 1939-40 of the National Trust. Here and there in the brief notes on the properties held by the Trust a hint is given of the difficulties which are being, or have had to be, overcome by those responsible for carrying out the objects of the Trust in securing that these objects shall not be irrevocably overridden, if that is at all possible, by the requirements of military authority or the necessities of food supply. The normal expansion of the work of the Trust cannot be expected to continue unimpaired in present conditions; and indeed the annual report for the period under review chronicles a reduction in receipts, not, indeed, as great as might be anticipated, which will make the realization of even working costs a matter of some anxiety. The work of the Trust, however, is, as has been said, of vital importance in maintaining much that is of the best in the national tradition, and its claims to public support should be among the last to be overlooked. An indication of the activity of the Trust in recent years is afforded by a comparative table given in the annual report, which shows that in the period 1914-40 there has been a tenfold increase in most of the figures. The number of properties has increased from 63 to $4 \mathrm{I} 0$, the acreage from 5,814 to 58,900 ; the capital raised and expended from $£ 59,861$ to $£ 530,114$, subscriptions from $£ 559$ to $£ 6,193$, and the gross income from properties from $£ 1,461$ to $£ 27,553$.

\section{Preserves from the Garden}

"Growmore" Bulletin No. 3, of the Ministry of Agriculture and Fisheries (H.M. Stationery Office, $4 d$.), presents in a concise and practical form instruction for the housewife in the preservation of surplus fruit and vegetables for winter use. Full directions are given for the making of jams, fruit jellies, cheeses, and syrups, and the bottling and canning of fruit and vegetables. Instructive notes are provided on the peculiarities of particular fruits and their suitability for the various methods of preservation. A selection of recipes for jam and jelly made from the more important fruits is included, and in some of these the normal amount of sugar has been reduced to meet the difficulties of sugar shortage. A useful feature is a statement of the expected yield of jam from the amounts of fruit used. Various methods are given for sterilizing fruit for canning and bottling and the preservation of fruit in the form of pulp. The latter is a useful method for the storage of large quantities of apples and plums without sugar.

The preservation of vegetables is not so widely practised as that of fruit, and as pressure cookers are recommended for vegetable sterilization, this method will not be extensively used in the average household Several vegetables may, however, be preserved by pickling, which is briefly dealt with in the bulletin. Salted runner beans are invariably satisfactory, and as salt is cheap and the method simple, more use should be made of this usually prolific crop. Many fruits and vegetables can be dried for future use, a method which needs no preservative, and is adequately treated in this bulletin. The authors, Alice Crang and Margery Mason, have produced a very usable handbook, and are to be congratulated on the selection of the most useful and straightforward methods, as well as on the omission of technical details which are of little interest to the average housewife.

\section{Organized Labour in Germany}

Alrhough written rather as if to prove a point, Dr. W. A. Robson's pamphlet, "Labour under Nazi Rule" (Oxford Pamphlets on World Affairs, No. 33. Pp. 32. Oxford: Clarendon Press. 3d. net) gives a concise and lucid account of the sweeping changes made by the Nazi regime in the status and organization of labour, from the liquidation of the highly progressive German working-class movement in 1933 to the system of unmitigated industrial conscription introduced since 1938. Prior to 1933, Germany was one of the most progressive countries in the world so far as the position of organized labour was concerned. By showing the extent to which industrial servitude and regimentation have been exacted as the price of Hitler's achievement in abolishing unemployment, Dr. Robson puts that achievement in its true perspective along with the Labour Front and the 'Strength through Joy' movement. This admirably written account of the present position of organized labour in Germany and the way in which it has arisen fully substantiates Dr. Robson's central thesis that the status, freedom, power, and conditions of 